\title{
Adherence to Cooperative Principles among Agricultural Cooperatives in Oyo State, Nigeria \\ Http://dx.doi.org/10.4314/jae.v20i1.12
}

\author{
Badiru, I.O. \\ Department of Agricultural Extension and Rural Development, \\ University of Ibadan, Nigeria. \\ E-mail: bodebadru@gmail.com \\ Phone: +2348034660732
}

Yusuf, K.F.

Department of Agricultural Extension and Rural Development, University of Ibadan, Nigeria.

E-mail:ka4larchade@yahoo.com

Phone: +2348038359154

Anozie, 0.

Department of Agricultural Extension and Rural Development, University of Ibadan, Nigeria.

E-mail: ogooranozie@gmail.com

Phone: +2348024273056

\section{Abstract}

This study assessed agricultural cooperatives' level of adherence to cooperative guiding principles in Oyo State, Nigeria. Multi stage sampling procedure was used to select 126 respondents for the study. Data on group characteristics, level of awareness, adherence and constraints to adherence to cooperative principles were collected using structured questionnaire and analysed using chi square at $5 \%$ level of significance. The mean year of existence of the cooperatives was $10 y e a r s$ while the mean membership size was 44. In addition, many of the cooperatives (44.4\%) were fairly strong financially. More than half (53.2\%) of the respondents had high level of awareness of the cooperative principles while $57.1 \%$ had high level of adherence to the principles. Meanwhile, inadequate financing and loan recovery difficulty $(\bar{x}=1.4$ each) were the main constraints to adherence to the principles. There was a significant relationship between respondents' level of awareness and adherence to the cooperative principles $\left(x^{2}=0.013, p \leq\right.$ 0.05). Agricultural cooperatives in the area largely adhered to the cooperatives principles. However, capacity building on innovative financial sourcing and loan recovery mechanisms should be embarked upon by management to enhance the adherence. 
Creative commons User License: CC BY-NC-ND

Abstracted by: EBSCOhost, Electronic Journals Service (EJS),

Google Scholar, Directory of Open Access Journals (DOAJ),

Journal Seek, Scientific Commons,

Food and Agricultural Organization (FAO), andCABI
Journal of Agricultural Extension

Vol. 20 (1) June, 2016

ISSN(e): 24086851; ISSN(Print); 1119944X

http://journal.aesonnigeria.org

http://www.ajol.info/index.php/iae

Email: editorinchief@aesonnigeria.org

Key words: Cooperatives principles, loan recovery, agricultural cooperatives, group adherence.

\section{Introduction}

Access to credit is crucial to agricultural and rural development. This is because it enhances productivity and improves the living standard of farmers (Adebayo and Adeola, 2008). Farmers require credit to adopt production innovations like improved seeds and seedlings, fertilizers, plant protection chemicals, pay labourers, equipment such as tractors, ploughs, harrows and ultimately increase efficiency of farm operation (Abu, Odoemenem and Ocholi, 2011).

In Nigeria, the demand for agricultural credit exceeds available resources and this poses a huge problem for the small scale farmers. According to Mgbakor, Uzendu and Ndubuisi (2014), the situation is aggravated by the fact that majority of the farmers are illiterate, do not keep records and also lack adequate collateral to access loans from formal institutions. In addition, the inability of farmers to open and run a current account which is a necessary condition to obtain loans from a bank also hinders farmers from accessing agricultural credits.

Although the government has over the years implemented several programmes to enhance small scale farmers' access to credit, Oruonye and Musa (2012) opine that the efforts achieved little impact due to factors such as financial, political and managerial problems, inadequate staff and equipment as well as the use of top-down approach. Hence, farmers rely more on informal and semi-formal sources of credits (Badiru, 2010). These sources include; savings, family and friends, village savings and loan association (VSLA), money lenders, rotating savings and credits association (RSCA), accumulating savings and credit association (ASCA) and agricultural cooperative societies, (AgriProFocus, 2011).

Among these informal and semi-formal sources, cooperative societies are the second most important sources of credit to small holders after friends and relatives (Badiru, 2010). Due to this level of importance, it is therefore not surprising that the establishment of agricultural cooperatives is on the increase in the country.

Agricultural co-operatives are agricultural-producer-owned cooperatives whose primary purpose is to increase members' production and incomes by helping with better link to finance, agricultural inputs, information, and output markets (Sifa, 2014). The International Cooperative Alliance (ICA, 1995) defines cooperative as an autonomous association of persons united voluntarily to meet their common economic, social, and cultural needs and aspirations through a jointly-owned and democratically-controlled enterprise. Thus, the values of cooperatives are self-help, self-responsibility, democracy, equity, equality and solidarity. This means that the sole purpose of the cooperative is to help one achieve one's objectives while at the same time assisting others in achieving theirs. 
Creative commons User License: CC BY-NC-ND

Abstracted by: EBSCOhost, Electronic Journals Service (EJS),

Google Scholar, Directory of Open Access Journals (DOAJ),

Journal Seek, Scientific Commons,

Food and Agricultural Organization (FAO), andCABI
Journal of Agricultural Extension

Vol. 20 (1) June, 2016

ISSN(e): 24086851; ISSN(Print); 1119944X

http://journal.aesonnigeria.org

http://www.ajol.info/index.php/iae

Email: editorinchief@aesonnigeria.org

According to FAO (2012) cooperatives play important roles in overcoming barriers and supporting small scale farmers. Evidence shows that efficient cooperatives have the capacity to empower their members economically and socially and to create sustainable employment through equitable and inclusive business models that are more resilient to shocks. Cooperatives offer small producers a range of services, aimed at improving:

- $\quad$ access to and management of natural resources;

- access to productive resources, technology and infrastructure to increase small producers' productivity and income generation;

- $\quad$ access to markets for goods and food distribution;

- $\quad$ access to information, knowledge and skills development to improve self-confidence and human capital;

- $\quad$ collective bargaining power in input and output markets; and

- $\quad$ active participation in decision-making, from the grassroots to policy formulation.

The services provided by cooperatives enable women and men smallholders to secure their needs and entitlements and to leverage market opportunities more effectively, thus contributing to poverty alleviation and the eradication of hunger.

In order to streamline the activities of cooperatives and ensure their efficiency, cooperative operations are guided by some principles. These principles are guidelines by which cooperatives put their values into practice. They include:

- $\quad$ Voluntary and open membership

- $\quad$ Democratic member control

- Member economic participation

- $\quad$ Autonomy and independence

- $\quad$ Education, training and information

- $\quad$ Cooperation among cooperatives

- $\quad$ Concern for community (ICA, 1995).

Considering the crucial role of agricultural cooperatives as arguably the best avenue to provide credit services to farmers, it is therefore necessary to examine how well these agricultural cooperatives operate with respect to adhering to these guiding principles in Oyo state.

In order to achieve this objective, the following specific objectives were set to:

1. determine the institutional characteristics of the cooperative societies in the study area.

2. ascertain respondents' awareness of the cooperative guiding principles;

3. identify constraints limiting the societies' adherence to cooperative guiding principles;

4. determine the level of respondents' adherence to cooperative guiding principles; and

5. examine the relationship between respondents' level of awareness and their adherence to cooperative guiding principles. 
Creative commons User License: CC BY-NC-ND

Abstracted by: EBSCOhost, Electronic Journals Service (EJS),

Google Scholar, Directory of Open Access Journals (DOAJ),

Journal Seek, Scientific Commons,

Food and Agricultural Organization (FAO), andCABI
Journal of Agricultural Extension

Vol. 20 (1) June, 2016

ISSN(e): 24086851; ISSN(Print); 1119944X

http://journal.aesonnigeria.org

http://www.ajol.info/index.php/jae

Email: editorinchief@aesonnigeria.org

\section{Methodology}

The study was carried out in Oyo state, one of the 36 states in Nigeria, with a population of $5,591,589$ people (Wikipedia, 2014). The state covers a total of 27,249 square kilometres of land mass. It is bounded in the south by Ogun state, in the north by Kwara state, in the east by Osun state and in the west; it is partly bounded by Ogun state and partly by the republic of Benin. Agriculture is the main occupation of the people of Oyo State. The climate in the state favours the cultivation of crops like maize, yam, cassava, sorghum, soybean, okra, pepper, guinea corn, melon, groundnut and rice (Wikipedia, 2014). As a result of these activities carried out in the state, cooperative activities in the state are high (EDInA, 2012).

A two-stage sampling procedure was employed to select respondents for the study. The first stage was the random selection of $60 \%$ (126) of the 210 registered agricultural cooperative societies in the state. The second stage was the random selection of an official (chairperson, general secretary or treasurer) of each selected cooperative to respond on behalf of the society.

Data for the study were collected with the aid of structured questionnaires and analysed using descriptive statistics such as percentages, mean and frequency while chi square was used to test the hypothesis. The dependent variable of the study is adherence to cooperatives guiding principles. This was operationalised by breaking down the guiding principles into various components and later expressed as statements, some of which the respondents were asked to indicate a yes/no and some others to which the respondents were asked to give responses as they occurred in their society. The level of adherence was then determined based on the pooled mean score for the group.

Level of awareness was measured by asking respondents to indicate their awareness of the co-operative guiding principles from a range of questions on the basis of yes or no and these were scored as 1 and 0 respectively. The mean score was later used to categorise the respondents' levels of awareness into low and high.

Constraints to adherence were measured by asking respondents to indicate the severity of a list of possible constraints to adhering to co-operative guiding principles using a 3-point scale of severe, mild or not a constraint. Severe was scored 2, mild as 1 and not a constraint as 0 .

\section{Results and Discussion}

Institutional Capacity of Respondents 
Creative commons User License: CC BY-NC-ND

Abstracted by: EBSCOhost, Electronic Journals Service (EJS),

Google Scholar, Directory of Open Access Journals (DOAJ),

Journal Seek, Scientific Commons,

Food and Agricultural Organization (FAO), andCABI
Journal of Agricultural Extension

Vol. 20 (1) June, 2016

ISSN(e): 24086851; ISSN(Print); 1119944X

http://journal.aesonnigeria.org

http://www.ajol.info/index.php/iae

Email: editorinchief@aesonnigeria.org

The mean year of existence of the agricultural cooperatives was 10.1 years. This implies that an average cooperative in the state has been in existence for 10 years. Since a large number of the cooperatives have been in existence for a long time, their responses represent entrenched societal disposition to the cooperative guiding principles over time. Majority (86.5\%) of the cooperatives had between 20-77 members with an average membership size of 43 members. Large membership suggests that cooperatives have grown over the years, as this may be an indication that the cooperative groups have built integrity over the years of their existence, which could also be a pointer to their adherence to the cooperative guiding principles.

A relatively high percentage of $18.3 \%$ and $44.4 \%$ of the cooperative groups rated their financial strength as weak and fair, respectively. This means that their financial strength is fairly weak. This implies that whatever finances the society had been enough only to a fair extent to meet the needs of their members. This may be an indication of weak financial status that often characterizes membership of most cooperative groups in Nigeria as hinted by Nwankwo, Ewuim and Asoya (2012). In any case, co-operatives without a functional self-financing feature and no reliable external finance may find it somewhat difficult to stand difficult times. The implication of a fairly weak financial strength on adherence is that some of the principles might not be adhered to since adhering to them requires finance which the cooperative societies may not be able to shoulder.

More than half (52.4\%) of the co-operative societies considered in this study loaned out the money realized as a society back to members. This implies that cooperatives are basically for self-help, where people pool their resources together to achieve a common goal. This finding corroborates that of Kareem, Arigbabu, Akintaro and Badmus (2012), that the major way by which co-operative societies increase cooperators capital formation is by granting timely loan to members.

With regards to cooperatives description, $64.3 \%$ were multi-purpose cooperatives. This is an indication that cooperatives engage in other income generating activities possibly to increase their financial strength and meet the needs of the members. This finding is at variance with that of EFInA (2012) that majority of co-operatives in Oyo state operated as credit and thrift societies.

More than three-quarter of the cooperatives in the state have affiliation with other cooperatives. This shows that there was a good relationship among co-operatives in the state, which will definitely promote free flow of information. This finding contradicts that of Nwankwo, Ewuim and Asoya (2012) that local rural cooperatives developed in isolation of each other. This may be due to the difference in the location, culture and orientation of the communities considered in the two studies.

However, almost all the co-operative societies considered in this study (98.4\%) did not have any international affiliations. The implication of this is that many cooperatives in the state may not be able to access international aid. 


\begin{tabular}{|c|c|c|c|}
\hline $\begin{array}{l}\text { Institutional } \\
\text { caharcteristics }\end{array}$ & Variable & Percentage & Mean \\
\hline \multirow[t]{5}{*}{ Years of existence } & $<6$ & 27.0 & \\
\hline & $7-11$ & 39.7 & Mean $=10.1$ \\
\hline & $12-16$ & 25.4 & $\mathrm{SD}=4.6$ \\
\hline & $17-21$ & 6.4 & \\
\hline & $22-26$ & 1.6 & \\
\hline \multirow[t]{4}{*}{ Membership capacity } & $<20$ & 10.3 & Mean $=43.5$ \\
\hline & $21-39$ & 35.7 & $S D=19.3$ \\
\hline & $40-49$ & 28.6 & \\
\hline & $>50$ & 25.4 & \\
\hline \multirow[t]{4}{*}{ Financial strength } & Weak & 18.3 & \\
\hline & Fair & 44.4 & \\
\hline & Strong & 29.4 & \\
\hline & Very strong & 7.9 & \\
\hline \multirow{3}{*}{$\begin{array}{l}\text { What societies do with } \\
\text { money }\end{array}$} & Save in bank & 5.6 & \\
\hline & Trade with it & 42.1 & \\
\hline & Loan out to members & 52.4 & \\
\hline \multirow[t]{2}{*}{ Society description } & Multi-purpose & 64.3 & \\
\hline & Credit and thrift & 35.7 & \\
\hline \multirow{4}{*}{$\begin{array}{l}\text { Affiliation with other } \\
\text { cooperatives } \\
\text { International affiliation }\end{array}$} & No & 14.3 & \\
\hline & Yes & 85.7 & \\
\hline & No & 98.4 & \\
\hline & Yes & 1.6 & \\
\hline
\end{tabular}

\section{Awareness of the Co-operative Guiding Principles}

Table 2, shows that respondents have a high level of awareness of cooperative guiding principles. Awareness on cooperative societies being a democratic one which gives each member equal right in decisions and policies making had the highest frequency (80.2\%) while, awareness on how cooperative movement should be strengthened through local, state, national, regional and international structures as a guiding principle $(40.5 \%)$ had the least frequency. This implies that respondents to a large extent are aware of what a cooperative should do and how it should operate. This knowledge will help members to ask questions when any principle is violated. This finding is in consonance with the findings of Toluwase and Apata (2011) that there was a high level of awareness about farmers' co-operatives which may be due to the advantages that have been derived by members. 


\section{Table 2: Distribution of respondents based on awareness of the co-operative guiding principle}

\begin{tabular}{|c|c|}
\hline Questions & $\%$ Yes \\
\hline Have you ever heard about cooperative guiding principles & 62.7 \\
\hline Are you aware that members should be taken freely into any cooperative society & 49.2 \\
\hline $\begin{array}{l}\text { Do you know that cooperatives are democratic society where members have right to } \\
\text { participate }\end{array}$ & 80.2 \\
\hline Are you aware that members should contribute equitably to society's capital & 70.6 \\
\hline $\begin{array}{l}\text { Are you aware that cooperatives are self-help organisations which should exist independent of } \\
\text { the government or any external organization }\end{array}$ & 46.0 \\
\hline Do you know that cooperatives are to train members, executives and employees & 47.6 \\
\hline $\begin{array}{l}\text { Are you aware that cooperative societies should inform the general public about the nature } \\
\text { and benefits of cooperation }\end{array}$ & 42.9 \\
\hline $\begin{array}{l}\text { Do you know that cooperatives are to strengthen cooperative movement through the local, } \\
\text { state, national, regional and international structures }\end{array}$ & 40.5 \\
\hline $\begin{array}{l}\text { Are you aware that cooperatives are to work for the sustainable development of their } \\
\text { communities through policies approved by their members } \\
\text { Overall awareness level: Low (range } 0-4,46.8 \% \text { ) High (range, } 5-9)=53.2 \%\end{array}$ & 65.9 \\
\hline
\end{tabular}

\section{Adherence to Co-operative Guiding Principles}

Table 3 reveals that all $(100 \%)$ cooperatives contributed money for the running of their societies and these societies gave adequate feedback to their members about their finances. The results further reveal that all $(100 \%)$ respondents posited that there is always punishment for non-attendance of the society's general meeting and that members know about the inflow and outflow of cash in the society. This implies that membership economic participation and flow of information have been important guiding principles that have sustained cooperative groups over the years. However, there is a low adherence to principle guiding the way societies chose their executives which more than half of the societies $(54.8 \%)$ posited were not done by everyone. The implication of this is that there would be an ineffective leadership which will have a negative impact on adherence to cooperatives principles and sustainability of the society. This agrees with the finding of Akinwumi (2006) who highlighted leadership as a critical factor affecting the success of agricultural cooperatives.

Cumulatively, Table 3 reveals that $57.1 \%$ of the cooperatives in the study area have high level of adherence to cooperative guiding principles. This implies that these cooperative societies understand that these principles are crucial to the continued existence and sustainability of the society. This is in line with the assertion of FAO (2010) which outlined some problems faced by cooperatives and concluded that, in 
Creative commons User License: CC BY-NC-ND

Abstracted by: EBSCOhost, Electronic Journals Service (EJS),

Google Scholar, Directory of Open Access Journals (DOAJ),

Journal Seek, Scientific Commons,

Food and Agricultural Organization (FAO), andCABI
Journal of Agricultural Extension

Vol. 20 (1) June, 2016

ISSN(e): 24086851; ISSN(Print); 1119944X

http://journal.aesonnigeria.org

http://www.ajol.info/index.php/iae

Email: editorinchief@aesonnigeria.org

order to ensure continue existences and sustainability of cooperative groups, it is important that members adhere strictly to the principles.

Table 3: Distribution of respondents based on adherence to co-operative guiding principles

\begin{tabular}{ll}
\hline Questions & $\%$ Yes \\
\hline Accept as members as many as indicate interest & 91.3 \\
Interested people pay registration fee before joining & 56.3 \\
Annual membership fees & 75.4 \\
Return on saving to members & 76.2 \\
Democratic process in appointing leaders & 45.2 \\
Members contribute money to run the society & 100 \\
Society organize special training for members & 65.1 \\
Punishment for non-attendance of your society's general meetings & 100 \\
Executives have a separate meeting arrangement & 96.8 \\
Availability of special training arrangement for the executives & 57.9 \\
Members know about the inflow and outflow of cash in the society & 100 \\
Overall adherence level: Low ( 42.9\%); High (57.1\%) &
\end{tabular}

Field survey (2015).

\section{Constraints to Adherence to the Co-operatives Guiding rinciples}

Table 4 reveals that the all the constraints were more than mild in terms of severity, as indicated by the means. The study further reveals that inadequate financing for the society and difficulty in getting loans back from members are the most severe of all the constraints identified by the study. This partly agrees with the findings of lbitoye (2012) that the most serious problems faced by co-operatives were inadequate capital accumulation, government interference and unavailability of loan. This may also be an indication of fairly weak financial strength as earlier reported (Table 1). The finding therefore implies that there may be difficulty in making loan available to members, and this may not be a good signal for a vibrant and effective cooperative society.

Table 4: Distribution of respondents based on constraints limiting societies' adherence to the guiding principles

\begin{tabular}{lll}
\hline Constraints & Mean & Rank \\
\hline Inadequate financing for the society & 1.4 & 1 \\
Difficulty in getting loans back from members & 1.4 & 1 \\
Illiteracy rate among members & 1.3 & 3 \\
Poor relationship among co-operative societies & 1.3 & 3 \\
Low returns on members' saving & 1.3 & 3 \\
High cost of training members & 1.3 & 3 \\
Dishonesty among union leaders & 1.3 & 3 \\
\hline Inadequate learned members to handle certain position & 1.2 & 8 \\
Members' dishonest attitude & 1.2 & 8 \\
Low knowledge about the guiding principles & 1.2 & 8 \\
Lack of commitment from members & 1.1 & 11 \\
Inability to get external aid & 1.1 & 11 \\
\hline
\end{tabular}


Source: Field survey (2015).

\section{Relationship between Rrespondents' Level of Awareness and their Adherence to Co-operative Guiding Principles}

Table 5 indicates a positive relationship between respondents' level of awareness and their adherence to co-operative guiding principles $\left(x^{2}=0.013, p \leq 0.05\right)$. This relationship was found to be significant. This implies that awareness of the guiding principles determines the societies' adherence to them. This is so because one cannot adhere to what one is not aware of; therefore, adherence is only possible when one is aware. This agrees with the findings of Azanza and Zamora-Luna (2005), who developed a cognitive behaviour model to evaluate adherence, which was based on the theory of experiential learning and observed that non awareness of guidelines was a major barrier to adherence.

Table 5: Relationship between respondents' level of awareness and their adherence to co-operative guiding principles

\begin{tabular}{lcccc}
\hline Variable & $\begin{array}{l}\text { Chi-square } \\
\text { value }\end{array}$ & $\begin{array}{c}\text { Degree of } \\
\text { freedom }\end{array}$ & P-value & Decision \\
\hline $\begin{array}{l}\text { Awareness } \\
\text { level }\end{array}$ & 6.297 & 1 & 0.013 & Significant \\
\hline
\end{tabular}

Source: Field survey (2015).

\section{Conclusion and Recommendation}

The study established that the cooperative groups in the study area largely adhered to the cooperative guiding principles. This high level of adherence was due to high level of awareness of the cooperative guiding principles among the officials of the societies. However, inadequate financing and inability of members to repay loans were the most limiting constraints to adherence. Capacity building on innovative financial sourcing and loan recovery mechanisms should be embarked upon by the management teams of apex cooperative bodies to enhance adherence while, governmental and non-governmental organisations should assist the apex bodies to establish affiliations with international cooperative societies for enhanced access to aids and opportunities.

\section{References}

Abu, G. A., Odoemenem, I. U. and Ocholi, A. (2011). Determining Optimum Farm Credit Need of Small Scale Farmers in Benue State. Journal of Economics and International Finance, 3(10), 564-570.

Adebayo, O. O., Adeola, R. G. (2008). Sources and Uses of Agricultural Credit by Small Scale Farmers in Surulere Local Government Area of Oyo State. Anthropologist, 10(4): 313-314.

AgriProFocus. (2011). A Guide for Small Holder Farmers on Saving, Credit and Effectively Managing Money for Improved Livelihoods: What You Need to Know to. In: Effectively Manage Money Matters, 
S. Musiime \& B. Atuha (Eds).1-26. SMJR Consult, Agri-Profocus: Uganda.

Akinwumi, J. (2006). Road Map to Re-engineering Cooperatives in Nigeria; A Paper Presented at the South-West Cooperative Leaders Conference, Organized by Cooperative Federation of Nigeria South West Zone at Obisesan Hall, Ibadan, September 7th.2006.

Azanza, M. V. P. and Zamora-Luna, M. B. V. (2005).Barriers of HACCP Team Members to Guidelines Adherence. Food Contro, 16(1), 15-22.

Badiru, I. O.(2010): Review of Small Farmer Access to Agricultural Credit in Nigeria. NSSP Brief No. 25. International Food Policy Research Institute.

Enhancing Financial Innovation and Access (EFInA). (2012). Understanding Cooperatives in Nigeria. Qualitative Report. 1-73.

Food and Agriculture Organisation (FAO). (2010). Promoting Employment and Entrepreneurship for Vulnerable Youths in West Bank and the Gaza

Strip, F. Dalla Valle. Rome. www.fao.org/docrep/012/i1450e/i1450e00.pdf

Food and Agriculture Organisation (FAO). (2012). Agricultural Cooperatives and Gender Equality. International Year of Cooperatives, Issue Brief Series.1-6. www.fao.org/gender/landrights.en

Ibitoye, S. J. (2012). Survey on the Performance of Agricultural Cooperative Societies in Kogi State, Nigeria. European Science Journal, 8(28), 98114.

International Cooperative Alliance (ICA). (1995). Report on the Centennial Congress of the ICA, Geneva, Switzerland, October.

Kareem, R. O., Arigbabu, Y. D., Akintaro, J. A. and Badmus, M. A. (2012).

The Impact of Cooperative Society on Capital Formation: A Case Study Temidere Cooperative and Thrift Society, ljebu-Ode, Ogun State, Nigeria. Global Journal of Science Frontier Research12(11), 17-29. Mgbakor, M. N., Uzendu, P. O. and Ndubuisi, D. O. (2014). Sources of Agricultural Credit to Small-Scale Farmers in Ezeagu Local Government Area of Enugu State, Nigeria. IOSR Journal of Agriculture and Veterinary Science (IOSR-JAVS), 7(8), 1-8.

Nwankwo, F., Ewuim, N. and Asoya, N. P. (2012). Role of Cooperative in Small and Medium Scale Enterprise (SMEs) Development in Nigeria: Challenges and the Way Forward. African Research Review Journal, 6(4), 140-156.

Odoemenem, I.U., Obinne, C.P.O. (2010). Assessing the Factors Influencing the Utilization of Improved Cereal Crop Production Technologies by Small

Scale Farmers in Nigeria. http://www.indjst.org/archive/vol.3.issue.2/innocent17.pdf

Oruonye, E. D. and Musa, Y. N. (2012). Challenges of Small Scale Farmers Access to Micro Credit (Bada Kaka) in Gassol LGA, Taraba State, Nigeria. Journal of Agricultural Economics and Development, 1(3), 62-68. 
Creative commons User License: CC BY-NC-ND

Abstracted by: EBSCOhost, Electronic Journals Service (EJS),

Google Scholar, Directory of Open Access Journals (DOAJ),

Journal Seek, Scientific Commons,

Food and Agricultural Organization (FAO), andCABI
Journal of Agricultural Extension

Vol. 20 (1) June, 2016

ISSN(e): 24086851; ISSN(Print); 1119944X

http://journal.aesonnigeria.org

http://www.ajol.info/index.php/iae

Email: editorinchief@aesonnigeria.org

Sifa, C. B. (2014). Role of Cooperatives in Agricultural Development and Food Security in Africa.

http://www.un.org/esa/socdev/documents/2014/coopsegm/Sifa--

Coops\%20and\%20agric\%20dev.pdf

Toluwase, S. O. and Apata, O. M. (2011). Impact of Farmers' Cooperative

Agricultural Productivity in Ekiti State, Nigeria. Greener Journal of Agricultural Science, 3(1), 63- 67.

Wikipedia. (2014). The Free Encyclopedia. Oyo State. Retrieved December 19,

2014 on from http://en.m.wikipedia.org/wiki/oyostate 